\title{
Ethnobotany of edible fruits used by the Mishmi tribes of Lohit District in Arunachal Pradesh, India
}

\author{
Sanjay Moyong ${ }^{1}$, Atek Nangkar ${ }^{1}$, Loxmi Jamo ${ }^{1}$, Bipul Ch. Kalita ${ }^{1}$, Jambey \\ Tsering ${ }^{2}$, Pallabi K. Hui ${ }^{3}$ and Hui Tag ${ }^{1,4}$ \\ 'Plant Systematic and Ethnobotanical Research Laboratory, Department of Botany, Rajiv Gandhi \\ University, Rono Hills, Doimukh - 791112, Arunachal Pradesh, India \\ ${ }^{2}$ Orchid Research Center, Tippi, Balukpong -790114, Arunachal Pradesh, India \\ ${ }^{3}$ Department of Biotechnology, National Institute of Technology-Arunachal Pradesh, Yupia-791112, Papum \\ Pare, Arunachal Pradesh, India \\ ${ }^{4}$ Corresponding Author; E-mail: huitag2008rgu@gmail.com
}

[Received 28.11.2019; Revised 22.12.2019; Accepted 26.2019; Published 31.12.2019]

\begin{abstract}
This paper discusses ethnobotany of the edible fruit plant species used by the Mishmi tribes of Lohit district in Arunachal Pradesh. Ethnobotanical investigation has revealed 37 species of wild fruit species belonging to 28 genera representing 22 angiospermic plant family. Tree represent highest number of 28 species which is followed by shrub and herbs. These commercially importance and some of the lesser known seasonal fruit species harvested mostly from the wild sources from community forest land, and consumed occasionally are actually helping the indigenous Mishmi community in supplementing the carbohydrate, proteins, fats, vitamins and mineral elements which is essential for the normal physiological function, alleviation of deficiency diseases, and help in preservation of ethnic food culture in their local biocultural landscape capable of sustaining the rural economy and livelihood.
\end{abstract}

Key words: Ethnobotany, Mishmi tribes, Edible fruit, Lohit District, Arunachal Pradesh.

\section{INTRODUCTION}

Edible fruit plants are crucial for maintaining health and wellbeing in humans since the time immemorial. The fresh wild fruits are the major sources of essential nutrients including vitamins, proteins, carbohydrates, fats and secondary metabolites of nutritional and medicinal interests (Prakash et al. 2012). The wild fruits of the Himalayas which are major source of antioxidant molecules capable of healing several human ailments including cancer and inflammation are often frequently harvested and consumed among the local tribal communities in different seasons of the year to supplement the nutritional requirement and to sustain their economy and livelihood of the rural household (Brahma et al. 2013; Pallabi et al. 2014). The state of Arunachal Pradesh with a total geographical area of 83,743 sq km area that falls within a geographical coordinate between $26.28^{\circ} \mathrm{N}$ and $29.30^{\circ} \mathrm{N}$ latitude and $91.20^{\circ} \mathrm{E}$ and $97.30^{\circ} \mathrm{E}$ longitude is falling within the Himalaya Biodiversity Hotspot endowed with rich biodiversity and ethnocultural heritage, diverse physiography and altitudinal variation (Myers et al. 2003; Mittermeier et al. 2005). This region which is blessed with 26 major tribes and 110 subtribes have the unique set of indigenous knowledge system on sustainable harvesting and utilization of food plants including wild edible fruits and vegetable plants of ethnobotanical and commercial significance (Tag 2007, 2014; Pallabi et al. 2014; Loxmi et al. 2017). The varied climatic condition ranging from hot and humid tropical low land to the temperate or 
even subalpine landscape with high humidity and rainfall not only favours luxuriant growth of forest vegetation but also support proliferation of edible fruit plants along different altitudinal gradient in the Arunachal Himalayan region of India (Dhar \& Nandargi 2004; Singh et al. 2007; Rinyo et al. 2018). Perusal of literature revealed that no publication is available to date on the edible fruits and vegetable plants used by the Mishmi community of Lohit district in Arunachal Pradesh except the first botanical exploration report of Kingdon Ward (1929, 1953). However, some ethnomedicinal publications are available on the Khamti community of Lohit district by Tag (2007) and Tag et al. (2007) which fundamentally dealt only on the ethnomedicinal aspects. Therefore, given the significance of edible fruit plants in sustaining economy and livelihood of the rural community, ethnobotanical field survey was conducted during the year 2017 - 2019 in the Mishmi localities of Lohit district in eastern Arunachal Pradesh with fundamental aims to enumerate and document the selected edible fruit plants traditionally used by the local community for sustaining the food and nutritional security, economy and livelihood. This paper discusses the scientific merits and scopes of edible fruits in sustaining rural nutritional and livelihood security in local and regional perspectives.

\section{MATERIALS AND METHODS}

\section{Study site and ethnocultural profile}

The Lohit District of Arunachal Pradesh with a total geographical area of $2402 \mathrm{sq} \mathrm{km}$ area falls within a geographical coordinate between $96^{\circ} 13^{\prime}$ and $96^{\circ} 15^{\prime}$ E longitude and $27^{\circ} 49^{\prime}$ and $27^{\circ} 53^{\prime}$ $\mathrm{N}$ latitude (Figure 1). Forests are all tropical to subtropical evergreen broad-leaved type with altitude ranging from $100-2000 \mathrm{~m}$ from AMSL and receives heavy rainfall from both northeast and southwest monsoon begins from May-September. The dominant tree species occupying the top storey are Altingia excelsa, Dillenia indica, Dipterocarpus retusus, Terminalia

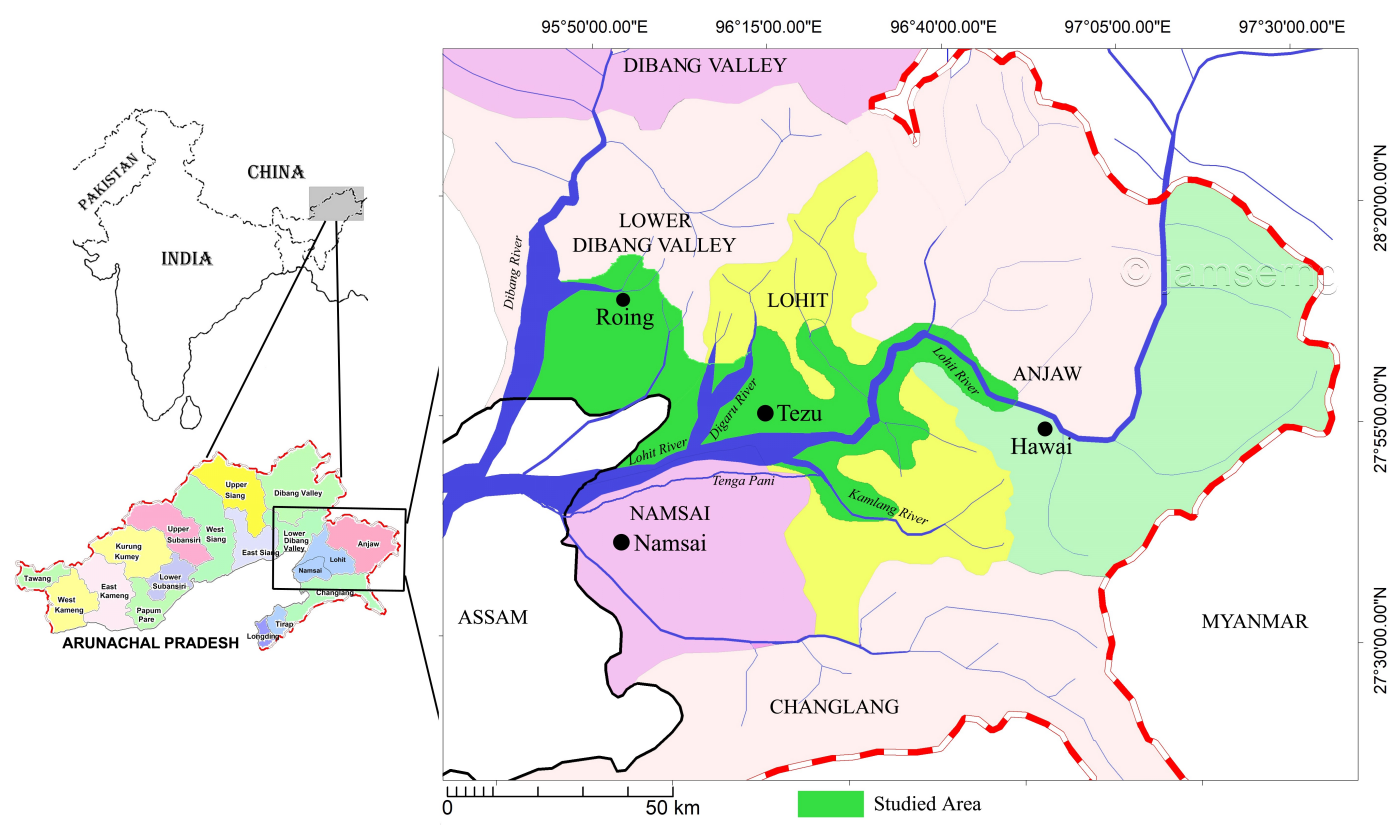

Figure 1. Map showing Mishmi inhabited Lohit and neighbouring districts of Arunachal Pradesh visited by the authors for collection of ethnobotanical information on edible fruits during the year $2018-2019$. 
myriocarpa, Tetramelis nudiflora and host of epiphytic herbs and climbers. The ground floor is populated with different herbaceous species of Zingiberaceae, Balsaminaceae, Liliaceae, Araceae, Arecaceae and Musaceae members (Tag et al. 2007). Of the total population of 1,45,726 souls (Anonymous 2011a), Mishmi population represent major chunk of the total population in the Lohit district of Arunachal Pradesh who belongs to mongoloid racial stock and speaks Midzu branch of Tibetan-Burman linguistic tone rich in traditional biocultural knowledge system. Mishmis of Lohit Valley are the worshipers of natural forces of the entire cosmos and follow reformed indigenous sect of religion called Nani-Intaya prevalent in their locality in pristine form. The Mizo Mishmi and Digaru Mishmi of Lohit celebrates traditional Tamladu festival while Edu Mishmi celebrates Reh festival with ancient ritualistic tradition to pray the almighty benevolent nature for blessings thus marking the arrival of new year and harvesting season with much fanfare (Anonymous 2011b).

\section{Rapid ethnobotanical appraisal}

Rapid ethnobotanical appraisal based survey for documentation of edible fruit plants in Mishmi dominated localities of Lohit district in Arunachal Pradesh was conducted during the years 2017 - 2019 following the method suggested by Martin (2008). A total of 25 household comprises of 50 local informants covering 15 villages focused on elderly age group, ranging between $40-80$ years, were contacted and interviewed using semi-structured questionnaire format for recording of ethnobotanical information on edible fruit species available in their local biocultural landscape. Prior Inform Consent (PIC) was taken from the potential informants before start of the work. The parts used, harvesting practices, climate and soil requirements, local uses and marketing scopes of each fruit species were recorded in digital camera and field note book. The voucher specimens were processed into mounted herbariumsheets of each species recorded following standard methodology (Jain \& Rao 1977). The specimens were taxonomically authenticated with the help of standard Flora of Assam (Kanjilal et al. 1934 - 1940), The Flora of British India (Hooker 1872 - 1897), Materials for the Flora of Arunachal Pradesh (Hajra et al. 1996; Giri et al. 2008; Chowdhery et al. 2009), and Flora of Lower Subansiri (Pal 1993). The accepted scientific names were verified in the website www.theplantlist.org and www.plantsoftheworldonline.org. The authenticated herbarium sheets, each bearing collection and accession numbers, were deposited in the Herbarium of Arunachal University (HAU), for the future reference.

\section{RESULT AND DISCUSSION}

\section{Taxonomic diversity, habit and part harvest}

The present investigations revealed a total of 37 species of wild edible fruit plants belonging to 28 genera from 22 plant families (Table 1; Plate I) those are reported to be used by the Mishmi community of Lohit district of Arunachal Pradesh as food supplements in their local landscape. Majority of the fruit species reported are consumed in raw at ripen stage, while some are consumed as vegetable and as pickle after fermentation. Out of 22 families, Moraceae is represented by highest number of 6 species (Figure 2). Of the total 37 species reported, tree represents highest number of 28 species which were followed by shrubs with 4 species, climbers 3 species and herbs with only 2 species (Figure 3 ).

\section{Commercially viable fruit species}

The commercially viable edible and medicinal tropical and subtropical fruit plants used by the Mishmi of Lohit districts commonly sold in markets are: Artocarpus heterophyllus, Averrhoa carambola, Baccaurea ramiflora, Castanopsis indica, Citrus limon, Citrus maxima, 
320 Wild edible fruits used by Mishmi tribe

Table 1. List of fruits plant species collected from Lohit District of Arunachal Pradesh

\begin{tabular}{|c|c|c|c|c|}
\hline Scientific Name & Habit & $\begin{array}{l}\text { Mishmi } \\
\text { name }\end{array}$ & $\begin{array}{l}\text { Parts } \\
\text { harvested }\end{array}$ & $\begin{array}{l}\text { Mode of } \\
\text { consumption }\end{array}$ \\
\hline $\begin{array}{l}\text { Artocarpus chama Buch.-Ham. } \\
\text { [Moraceae]; SM/HT/HAU/1772/2018 }\end{array}$ & Tree & Manlangsit & Fruits & Raw \\
\hline $\begin{array}{l}\text { Artocarpus lacucha } \text { Buch.-Ham. } \\
\text { [Moraceae]; SM/HT/HAU/1778/2018 }\end{array}$ & Tree & Haabang & Fruits & Raw \\
\hline $\begin{array}{l}\text { Artocarpus heterophyllus Lam. } \\
\text { [Moraceae]; SM/HT/HAU/1773/2018 }\end{array}$ & Tree & Dabyum & $\begin{array}{l}\text { Fruits, } \\
\text { young } \\
\text { leaves }\end{array}$ & Raw \\
\hline $\begin{array}{l}\text { Averrhoa carambola L. [Oxalidaceae]; } \\
\text { SM/HT/HAU/1777/2018 }\end{array}$ & Tree & $\begin{array}{l}\text { Dablai } \\
\text { shai }\end{array}$ & Fruits & Raw \& pickle \\
\hline $\begin{array}{l}\text { Baccaurea ramiflora } \text { Lour. } \\
\text { [Phyllanthaceae]; } \\
\text { SM/HT/HAU/1779/2018 }\end{array}$ & Tree & Soobeey & Fruits & Raw \\
\hline $\begin{array}{l}\text { Calamus tenuis Roxb. [Arecaceae]; } \\
\text { SM/HT/HAU/1782/2019 }\end{array}$ & Climber & $\begin{array}{l}\text { Lakaa } \\
\text { shi/Kanche } \\
\text { e }\end{array}$ & Fruits & Raw \\
\hline $\begin{array}{l}\text { Calamus viminalis Willd. [Arecaceae]; } \\
\mathrm{SM} / \mathrm{HT} / \mathrm{HAU} / 1781 / 2019\end{array}$ & Climber & $\begin{array}{l}\text { Lauraa/Ma } \\
\text { itul }\end{array}$ & Fruits & Raw \\
\hline $\begin{array}{l}\text { Canarium strictum Roxb. [Burseraceae]; } \\
\text { SM/HT/HAU/1783/2019 }\end{array}$ & Tree & Ney-klaa & Fruits & Raw \\
\hline $\begin{array}{l}\text { Caryota urens L. [Arecaceae]; } \\
\text { SM/HT/HAU/1785/2019 }\end{array}$ & Tree & $\begin{array}{l}\text { Deeing or } \\
\text { Taksi }\end{array}$ & Fruits & Raw \\
\hline $\begin{array}{l}\text { Castanopsis hystrix Hook.f. \& Thomson } \\
\text { ex A.DC. [Fagaceae]; } \\
\text { SM/HT/HAU/1788/2019 }\end{array}$ & Tree & $\begin{array}{l}\text { Ayaykrong } \\
\text { sit or } \\
\text { Tapoisit }\end{array}$ & Seeds & Raw \\
\hline $\begin{array}{l}\text { Castanopsis indica (Roxb. ex Lindl.) } \\
\text { A.DC. [Fagaceae]; } \\
\text { SM/HT/HAU/1701/2019 }\end{array}$ & Tree & Ayaysit & Seeds & Raw \\
\hline $\begin{array}{l}\text { Citrus limon (L.) Osbeck [Rutaceae]; } \\
\text { SM/HT/HAU/1703/2019 }\end{array}$ & Shrub & $\begin{array}{l}\text { Pasing } \\
\text { tahee }\end{array}$ & Fruits & Raw \& pickle \\
\hline $\begin{array}{l}\text { Citrus maxima (Burm.) Merr. [Rutaceae]; } \\
\mathrm{SM} / \mathrm{HT} / \mathrm{HAU} / 1702 / 2019\end{array}$ & Tree & $\begin{array}{l}\text { Passing- } \\
\text { sig/Tikki }\end{array}$ & Fruits & Raw \& pickle \\
\hline $\begin{array}{l}\text { Choerospondias axillaris (Roxb.) B.L.Burtt } \\
\text { \& A.W.Hill [Anacardiaceae]; } \\
\text { SM/HT/HAU/1706/2019 }\end{array}$ & Tree & $\begin{array}{l}\text { Mudhu- } \\
\text { shei }\end{array}$ & Fruits & Raw \& pickle \\
\hline $\begin{array}{l}\text { Dillenia indica L. [Dilleniaceae]; } \\
\mathrm{SM} / \mathrm{HT} / \mathrm{HAU} / 1708 / 2019\end{array}$ & Tree & Zoopa-shei & Fruits & Raw \& boil \\
\hline $\begin{array}{l}\text { Elaeagnus latifolia } \mathrm{L} \text {. [Elaeagnaceae]; } \\
\text { SM/HT/HAU/1709/2019 }\end{array}$ & Shrub & Sahasit & Fruits & Raw \\
\hline $\begin{array}{l}\text { Ficus auriculata Lour. [Moraceae]; } \\
\text { SM/HT/HAU/1707/2019 }\end{array}$ & Tree & Aapo & Fruits & Raw \\
\hline $\begin{array}{l}\text { Ficus semicordata } \text { Buch.-Ham. ex Sm. } \\
\text { [Moraceae]; SM/HT/HAU/1710/2019 }\end{array}$ & Tree & Beesheii & Fruits & Raw \\
\hline $\begin{array}{l}\text { Garcinia dulcis (Roxb.) Kurz } \\
\text { [Clusiaceae]; SM/HT/HAU/1715/2019 }\end{array}$ & Tree & Jawpasit & Fruits & Raw \& pickle \\
\hline $\begin{array}{l}\text { Hodgsonia macrocarpa (Blume) Cogn. } \\
\text { [Cucurbitaceae]; SM/HT/HAU/1712/2019 }\end{array}$ & Climber & Duwra & Fruits, seeds & Roasted \\
\hline
\end{tabular}


Sanjay Moyong et al. 321

\begin{tabular}{|c|c|c|c|c|}
\hline Scientific Name & Habit & $\begin{array}{l}\text { Mishmi } \\
\text { name }\end{array}$ & $\begin{array}{l}\text { Parts } \\
\text { harvested }\end{array}$ & $\begin{array}{l}\text { Mode of } \\
\text { consumption }\end{array}$ \\
\hline $\begin{array}{l}\text { Livistona jenkinsiana Griff. [Arecaceae]; } \\
\mathrm{SM} / \mathrm{HT} / \mathrm{HAU} / 1716 / 2019\end{array}$ & Tree & Laaka & Fruits & Raw \\
\hline $\begin{array}{l}\text { Melastoma malabathricum } \text { L. } \\
\text { [Melastomataceae]; } \\
\text { SM/HT/HAU/1720/2019 }\end{array}$ & Shrub & $\begin{array}{l}\text { Manchusa } \\
\text { yah or } \\
\text { Darah }\end{array}$ & Fruits & Raw \\
\hline $\begin{array}{l}\text { Morus indica } \mathrm{L} . \text { [Moraceae]; } \\
\text { SM/HT/HAU/1735/2019 }\end{array}$ & Shrub & Khrosit & Fruits & Raw \\
\hline $\begin{array}{l}\text { Musa balbisiana Colla [Musaceae]; } \\
\text { SM/HT/HAU/1716/2019 }\end{array}$ & Herb & $\begin{array}{l}\text { Khamburo } \\
o\end{array}$ & Fruits & Raw \\
\hline $\begin{array}{l}\text { Neolamarckia cadamba (Roxb.) Bosser } \\
\text { [Rubiaceae]; SM/HT/HAU/1709/2019 }\end{array}$ & Tree & Kaa-daam & Fruits & Raw \\
\hline $\begin{array}{l}\text { Nephelium lappaceum L. [Sapindaceae]; } \\
\text { SM/HT/HAU/1718/2019 }\end{array}$ & Tree & $\begin{array}{l}\text { Ahted seeh } \\
\text { or Aathiak }\end{array}$ & Fruits & Raw \\
\hline $\begin{array}{l}\text { Oroxylum indicum (L.) Kurz. } \\
\text { [Bignoniaceae]; SM/HT/HAU/1722/2019 }\end{array}$ & Tree & $\begin{array}{l}\text { Tachagam } \\
\text { digro }\end{array}$ & Seed & Raw \\
\hline $\begin{array}{l}\text { Pandanus dubius Spreng. [Pandanaceae]; } \\
\text { SM/HT/HAU/1726/2019 }\end{array}$ & Tree & Hangrab & Fruits & Raw \\
\hline $\begin{array}{l}\text { Persicaria chinensis (L.) H. Gross } \\
\text { [Polygonaceae]; SM/HT/HAU/1728/2019 }\end{array}$ & Herb & $\begin{array}{l}\text { Tah-shee } \\
\text { timtim }\end{array}$ & Fruits & Raw \\
\hline $\begin{array}{l}\text { Phyllanthus emblica } \text { L. [Phyllanthaceae]; } \\
\text { SM/HT/HAU/1732/2019 }\end{array}$ & Tree & Anlokhi & Fruits & Raw \& pickle \\
\hline $\begin{array}{l}\text { Pinanga gracilis Blume [Arecaceae]; } \\
\text { SM/HT/HAU/1736/2019 }\end{array}$ & Tree & Laraao & Fruits & Raw \\
\hline $\begin{array}{l}\text { Prunus persica (L.) Batsch [Rosaceae]; } \\
\text { SM/HT/HAU/1724/2019 }\end{array}$ & Tree & Aam-toh & $\begin{array}{l}\text { Whole fruits } \\
\text { except seed }\end{array}$ & Raw \\
\hline $\begin{array}{l}\text { Pyrus communis L. [Rosaceae]; } \\
\text { SM/HT/HAU/1733/2019 }\end{array}$ & Tree & Glung & Whole fruits & Raw \\
\hline $\begin{array}{l}\text { Spondias pinnata (L.f.) Kurz } \\
\text { [Anacardiaceae]; } \\
\text { SM/HT/HAU/1734/2019 }\end{array}$ & Tree & Dablai & Fruits & Raw \\
\hline $\begin{array}{l}\text { Sterculia monosperma Vent. } \\
{[\text { Malvaceae]; SM/HT/HAU/1739/2019 }}\end{array}$ & Tree & $\begin{array}{l}\text { Haa giyoo } \\
\text { sai / } \\
\text { Lakousit }\end{array}$ & $\begin{array}{l}\text { Yellowish } \\
\text { core part }\end{array}$ & Raw \& roasted \\
\hline $\begin{array}{l}\text { Sterculia villosa Roxb. [Malvaceae]; } \\
\text { SM/HT/HAU/1745/2019 }\end{array}$ & Tree & Aagyoo & Seeds & Raw \\
\hline $\begin{array}{l}\text { Terminalia chebula } \text { Retz. } \\
\text { [Combretaceae]; SM/HT/HAU/1742/2019 }\end{array}$ & Tree & $\begin{array}{l}\text { Kiangsa } \\
\text { ama }\end{array}$ & Fruits & Raw \& dry \\
\hline
\end{tabular}

Dillenia indica, Musa balbisiana, Phyllanthus emblica, and Terminalia chebula. These species have been observed to be widely harvested and consumed by the local farmers and popularly sold in local markets of Tezu mostly by the women folk and rural marginal farmers to sustain their livelihood.

\section{Conservation and harvesting}

The traditional seasonal edible fruit species conserved in the community forest land and harvested for carbohydrates, fat, protein, vitamin and mineral sources are: Artocarpus chama, 

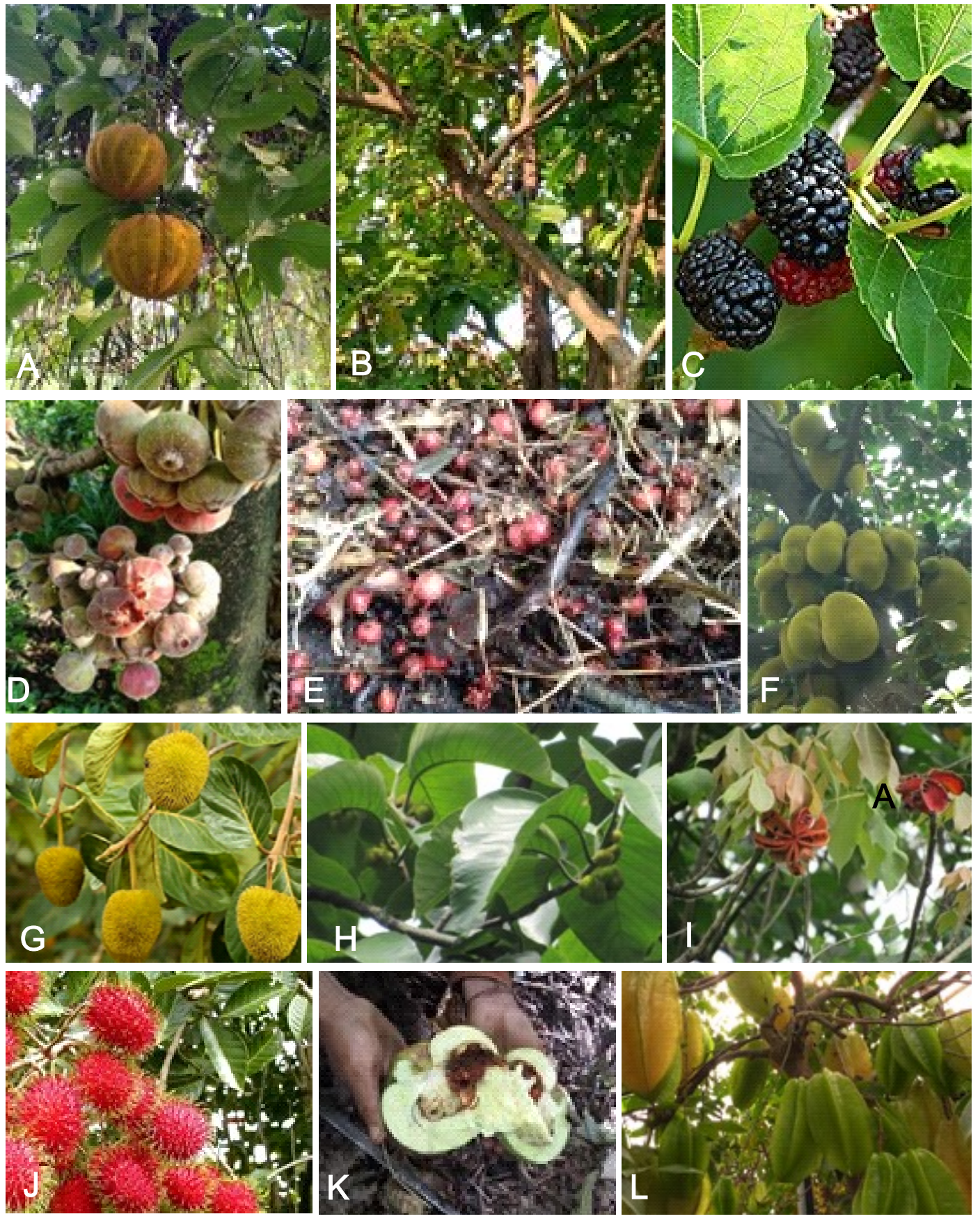

PLATE - I. Images of some collected edible wild fruits from Lohit district, Arunachal Pradesh: A. Hodgsonia macrocarpa; B. Baccaurea ramiflora; C. Morus indica; D. Ficus auriculata; E. Ficus semicordata; F. Artocarpus heterophyllus; G. Artocarpus chama; H. Artocarpus lacucha; I. Sterculia villosa; J. Nephelium lappaceum; K. Dillenia indica (spilled fruit); L. Averrhoa carambola. 


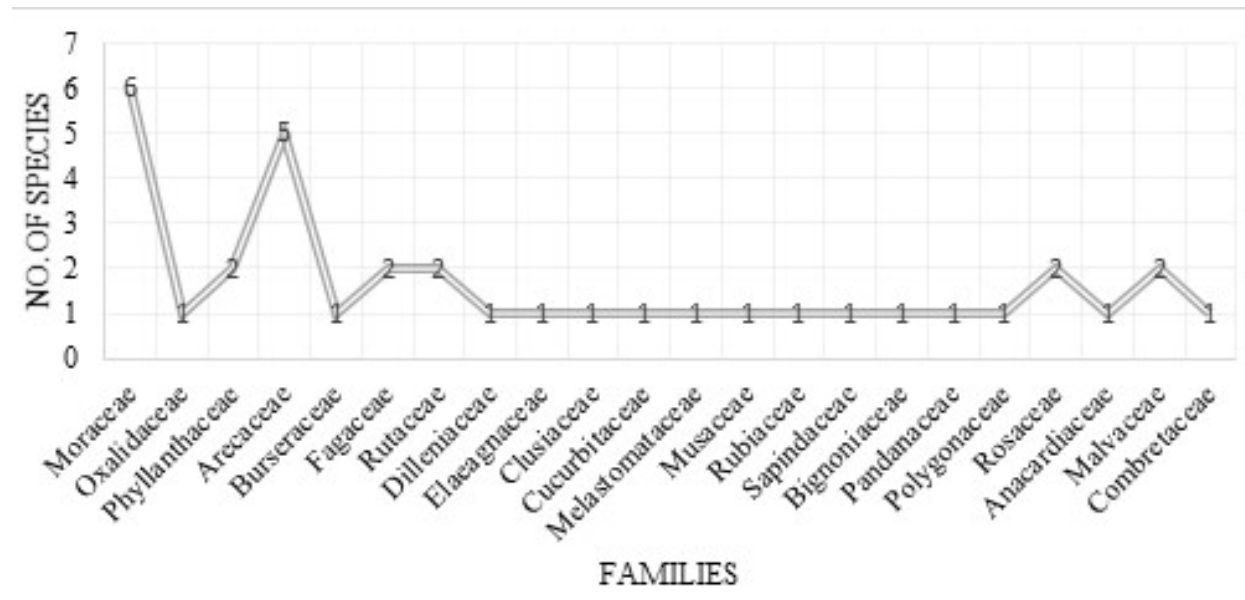

Figure 2. Distribution of fruit plant species within 22 families recorded from Lohit Valley of Arunachal Pradesh.

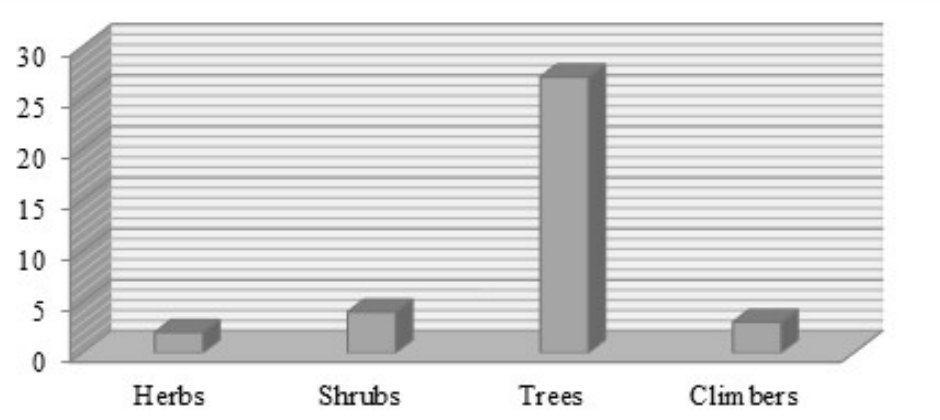

Figure 3. Habit of the edible fruit plant species $(\mathrm{n}=37)$ used by the Mishmi tribes of Lohit valley in Arunachal Pradesh

Artocarpus lacucha, Artocarpus heterophyllus, Elaeagnus latifolia, Ficus auriculata, Ficus semicordata, and Hodgsonia macrocarpa. These are the seasonal fruits collected from the community forest-land periodically by the local villagers - young and old as essential nutrient and herbal supplement to keep their body healthy. Validation studies have suggested these wild fruits species possessing the high amount of anti-oxidant molecule which are potential to treat and prevent cancer and inflammation related ailments caused by the free radicals generated in the cell due to excessive consumption of toxic and corrosive food items (Pallabi et al. 2014; Loxmi et al. 2017).

\section{CONCLUSION}

Present rapid appraisal based ethnobotanical report on the Mishmi community of Lohit Valley of Arunachal Pradesh have revealed that the local tribal farmers of the valley are rich in traditional knowledge related to conservation, cultivation, sustainable harvesting and marketing of the wild edible food and medicinal fruit plants available in their local landscape. Majority of the fruits harvested and sold in the local market are derived from the wild sources conserved in the community forest area whereas few species were found to be cultivated in the horticultural plots. The fruits harvested are mostly consumed by the local residents in raw and value added products such as pickle which are good sources of vitamins, essential 
minerals, carbohydrate, protein and fats, and anti-oxidant molecules for keeping good health and longevity. Phytochemical, nutritional and pharmacological validation studies on some selected biochemically unexplored species is required to ascertain nutritional and nutraceutical potentials. To improve rural livelihood and nutritional security, prospective local farmers should be encouraged to cultivate commercially significant species in community forest area and waste land for effective conservation and sustainable utilization in the target biocultural landscape.

\section{Acknowledgements}

The authors are thankful to DBT GoI New Delhi under NER and Twinning programme for funding support to RGU; DST SERB New Delhi; DBT GoI New Delhi, GBPNIHESD Almora under IERP scheme for funding support to NIT-AP. The first author is thankful UGC New Delhi for PhD fellowship support through RGU. The authors are deeply thankful to the traditional knowledge holders of the Mishmi community of Lohit district of Arunachal Pradesh for logistic support and sharing their valuable ethnobotanical information on edible fruit plant species during field survey.

\section{LITERATURE CITED}

Anonymous, 2011a. Census Report: Arunachal Pradesh. Ministry of Home Affairs, Government of India. Pp. 5 - 20.

Anonymous, 2011b. Statistical handbook of Lohit District of Arunachal Pradesh. District Statistical Office, Tezu, Deputy Commissioner Lohit, Arunachal Pradesh. Pp- 3 - 10.

Brahma, S; Narzary, H \& Basumatary, S. 2013. Wild edible fruits of Kokrajhar district of Assam, North-East India. Asian J. Pl. Sci. Res. 3(6): 95 - 100.

Chowdhery, H.J; Giri, G.S; Pal, G.D; Pramanik, A \& Das, S.K. 2009. Materials for the flora of Arunachal Pradesh. Vol. III. Botanical Survey of India, Kolkata

Dhar, O.N \& Nandargi, S. 2004. Rainfall distribution over the Arunachal Pradesh Himalayas. Weather 59 (6): 155 - 157.

Giri, G.S.; Pramanik, A. \& Chowdhery, H.J. 2008. Materials for the Flora of Arunachal Pradesh. Vol. II. Botanical Survey of India, Kolkata.

Hajra, P.K.; Verma, D.M. \& Giri, G.S. 1996. Materials for the Flora of Arunachal Pradesh. Vol. I. Botanical Survey of India, Calcutta.

Hooker, J.D. 1872 - 1897. The Flora of British India, Vols. 1-7. L. Reeve \& Co Ltd, Ashford, Kent, London.

Jain, S.K \& Rao, R.R. 1977. A Hand Book of Field and Herbarium Methods, Pp $1-70$. Today \& tomorrow's Printers \& Publishers, New Delhi.

Kanjilal, U.N; Das, A.; Kanjilal, P.C.; Purkaystha, C.; De, R.N. \& Bor, N.L. $1934-1940$. Flora of Assam (Vols. I - V). Govt of Assam Press, Shillong

Kingdon Ward, F. 1929. Botanical exploration in the Mishmi Hills. J. Himalaya 1: 51 - 59.

Kingdon Ward, F. 1953. Flora of Lohit Valley in 1950. Proceeding of Linnaean Society London, 164: 2 - 8.

Loxmi J; Pallabi K; Debmalya D.G \& Tag, H. 2017. Ethnobotany and nutritional potential of Gonostegia hirta (Blume ex Hassk.) Miq. (Urticaceae) from Arunachal Pradesh, India. Pleione 11(2): 329 - 335.

Martin, G.J. 2008. Ethnobotany: A Methods Manual, People and Plants Conservation Series. Earthscan, UK and USA. Pp. $10-160$. 
Mittermeier, R.A.; Gil, P.R.; Hoffmann, M.; Pilgrim, J.; Brooks, T.; Mittermeier, C.G.; Lamoreux, J.; Da Fonseca, G.A.B. 2005. Hotspots Revisited: Earth's Biologically Richest and Most Endangered Terrestrial Ecoregions. Conservation International.

Myers, N. 2003. Biodiversity hotspots revisited. BioScience 53: 916 - 917.

Pal, G.D. 1993. Flora of Lower Subansiri District, Arunachal Pradesh, India. A Ph.D thesis submitted to the University of Calcutta for award of Degree of Doctor of Philosophy in Botany. (Unpublished). Pp. 8-126.

Pallabi, K; Tag, H; Sarma, H.N \& Das, A.K. 2014. Evaluation of Nutritional Potential of Five Unexplored Wild Edible Food Plants from Eastern Himalayan Biodiversity Hotspot Region (India). International J. Biol., Life Sci. Engin. 8(3): 1 - 4.

Prakash, D; Upadhyay, G; Gupta, C; Pushpangadan, P \& Singh, K.K. 2012. Antioxidant and free radical scavenging activities of some promising wild edible fruits. Intn. Food Res. J. 19 (3):1109 - 1116.

Rinyo, R; Momang, T; Pallabi, K.H \& Tag, H. 2018. Ethnobotanical resources and traditional skills prevalent among the Tagin community of Arunachal Pradesh, India. Pleione 12(2): $265-274$.

Singh, R.K; Singh, A \& Sureja, A.K. 2007. Traditional foods of Monpa tribe of West Kameng, Arunachal Pradesh. Indian J. Trad. Knowl. 6(1): 25 - 36

Tag, H. 2007. A systematic study of plants of ethnomedicinal importance used by the Khamti Tribe of Arunachal Pradesh. A Ph.D thesis submitted to Rajiv Gandhi University for award of Degree of Doctor of Philosophy in Botany (unpublished). Pp. $15-45$.

Tag, H. 2014. Biodiversity, Traditional Knowledge, Intellectual Property Rights and Benefit Sharing in the Context of Northeast India. In: Behera, M.C. \& Jumyir, B. (eds.), Resources, Tribes and Development. Rawat Publications, Jaipur. Pp. 259 - 279.

Tag, H; Das, A.K \& Harry, H. 2007. Anti-inflammatory plants used by the Khamti tribe of Lohit district eastern Arunachal Pradesh, India. Nat. Prod. Rad. 6 (4): 334 - 340.

http://www.theplantlist.org

http://www.plantsoftheworldonline.org/ 